THE ENGLISH LINE 
Also by John Powell Ward:

Poetry and the Sociological Idea (1981)

Wordsworth's Language of Men (1984)

Raymond Williams (1981)

The Poetry of R. S. Thomas (1987)

To Get Clear (poems) (1981)

The Clearing (poems) 1984) 


\section{THE ENGLISH LINE}

Poetry of the Unpoetic from Wordsworth to Larkin

John Powell Ward

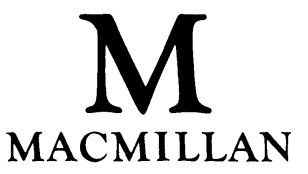


All rights reserved. No reproduction, copy or transmission of this publication may be made without written permission.

No paragraph of this publication may be reproduced, copied or transmitted save with written permission or in accordance with the provisions of the Copyright, Designs and Patents Act 1988, or under the terms of any licence permitting limited copying issued by the Copyright Licensing Agency, 33-4 Alfred Place, London WC1E TDP.

Any person who does any unauthorised act in relation to this publication may be liable to criminal prosecution and civil claims for damages.

First published 1991

Published by

MACMILLAN EDUCATION LTD

Houndmills, Basingstoke, Hampshire RG21 2XS

and London

Companies and representatives

throughout the world

Phototypeset by Input Typesetting Ltd, London

\section{British Library Cataloguing in Publication Data}

Ward, J. P. (John Powell) 1937-

The English line : poetry of the unpoetic from Wordsworth to Larkin.

1. Poetry in English - Critical studies

I. Title

821.009

ISBN 978-0-333-47169-2

DOI 10.1007/978-1-349-21481-5 


\section{Contents}

Preface

Acknowledgements

vi

vii

Chapter 1 Introduction

PART I

Chapter 2 Wordsworth's Precursors 25

Chapter 3 William Wordsworth 34

Chapter 4 Samuel Taylor Coleridge and John Clare 52

PART II

Chapter 5 Alfred Lord Tennyson and Matthew Arnold 63

Chapter 6 Emily Brontë, Christina Rossetti, Elizabeth Barrett Browning - Gerard Manley

Hopkins

PART III

Chapter 7 Thomas Hardy

Chapter 8 A. E. Housman, Wilfred Owen and Edward Thomas

Chapter 9 Robert Frost

\section{PART IV}

Chapter 10 Louis MacNeice and Dylan Thomas

Chapter 12 Conclusion

Texts Used for Main Poets Discussed 


\section{Preface}

Writing on several poets at once, one draws on man resources. For intellectual stimulus and their patience and sur port in various ways, times and places, I am indebted $t$ Dannie and Joan Abse, Peter Forbes, Jeremy Hooker, Sue Ror Gordon Stuart and John Turner; to Beverley Tarquini, Carolin Egar, Alison Kelly and Sue Cope of Macmillan; to my wif and sons, as always; to University of London extramural stuc ents at Ongar, Essex; and most of all (because the idea for th book came from their stimulus) to the students who took $\mathrm{m}$ course on twentieth-century poetry at University Collegi Swansea, in 1985-8.

John Powell WaR 


\section{Acknowledgements}

The author and publishers would like to thank the following for permission to quote copyright material: the Estate of Robert Frost, Jonathan Cape Ltd and Henry Holt \& Co. Inc. (USA) for excerpts from 'Home Burial', 'The Mountain', 'Mending Wall', 'The Ax-Helve', 'Stopping by Woods on a Snowy Evening', 'After Apple-Picking', 'The Oft-Repeated Dream' and 'Tree at my Window' from The Poetry of Robert Frost edited by Edward Connery Lathem; and the Trustees for the copyright of the late Dylan Thomas, J. M. Dent \& Sons Ltd and New Directions Publishing Corporation (USA) for excerpts from 'Fern Hill', 'Poem in October' and 'The Force that through the Green Fuse'. Extracts from High Windows, The Whitsun Weddings and Collected Paems by Philip Larkin; from 'Autumn Journal' from The Collected Poems of Louis MacNeice; and from 'In Memory of Sigmund Freud' from Collected Poems by W. H. Auden are reprinted by permission of Faber and Faber Ltd. The excerpt from 'This Be The Verse' from High Windows by Philip Larkin (copyright (C) 1974 by Philip Larkin) is reprinted by permission of Farrar, Straus and Giroux, Inc. (USA). The excerpt from 'An Interview with The Observer' from Required Writing by Philip Larkin (copyright (C) 1983 by Philip Larkin) is reprinted by permission of Farrar, Straus and Giroux, Inc. (USA). The excerpt from 'In Memory of Sigmund Freud' by W. H. Auden is reprinted by permission of Random House, Inc. (USA). 
Hardy's poems belong to an English tradition that goes bac to Romantic poets like Wordsworth and John Clare, an beyond them to the anonymous beginnings of the Englis. lyric in the Middle Ages. It is a poetry, essentially, of norme tive experience: plain, low-pitched, physical and abiding. : says that life goes on, and that human beings think and fet in much the same way from one generation to another, an from one century to another, and that because they thin and feel, they are capable of tragedy, and of poetry. It $i$ the principal tradition in English verse.

\section{Samuel Hynes}

La mélancholie n'est pas française

$$
\text { Julia Kristeva }
$$

$\mathrm{He}$ is the poet of unpoetical natures

John Stuart Mill (on Wordsworth)

O woe, woe, etcetera

$$
\text { Ezra Pound (on Housman) }
$$

Some time ago I agreed to judge a poetry competition - yo know, the kind where they get about 35,000 entries, an you look at the best few thousand. After a bit I said, wher are all the love poems? And nature poems? And they saic $\mathrm{Oh}$, we threw all those away. I expect they were the one I should have liked.

$$
\text { Philip Larkin }
$$

Does the land wait the sleeping lord

$$
\text { or is the wasted land }
$$

that very lord who sleeps? 